another rent in an opposite direction at an angle of exactly $32^{\circ}$. The brick shaft of the mill stands by itself, and is about 40 feet high. The upper part, ten feet from the top, is broken right through, evidently by the swaying motion, and is twisted round on the lower part one inch and a half towards the south-east. The size of the chimney at this part is 3 feet 9 inches square.

In view of Mr. Topley's suggestion that the earthquake may have some connection with the underlying ridge of Palæozoic rocks, it would be interesting to know if any shocks were felt in the Boulonnais and the Ardennes.

Ipswich Museum

AT the Cross Farm, East Mersea, on April 25, I was shown in the garden two places where water, it was said, spouted up shortly after the shock on the 2and. They were about ten yards apart on a freshly dug piece of ground on a slight slope, and the woman who lived in the house close by informed me that after the shock she had observed water spouting out from them, and that it continued to do so until after her dinner, which was at one o'clock, when it ceased. There was enough water she said to cause a small stream to run down from each place towards her house, where they formed a puddle; her husband tasted the water and told her it was brackish. There was still evidence of the truth of this statement : the earth at each spot was damp, as was also a small channel which the water had made rurning down the slope. It appeared as if a small underground water-pipe had burst and the water had been forced above the surface. Cross Farm, I believe, is about a quarter of a mile from the sea, and perhaps twenty feet above its level. EDWARD NEWTON

Lowestoft, May 5

This village lies partly on the lowest beds of the Chalk, and partly on the Gault; it is between $N^{+}$. lat. $51^{\circ} 49^{\prime}$ and $5 \mathrm{I}^{\circ} 5 \mathrm{O}^{\prime}$, and $W$. long. $0^{\circ} 4 \mathrm{O}^{\prime}$ and $\mathrm{O}^{\circ} 4 \mathrm{I}^{\prime}$. The shock was felt at the church, and at two cottages where are invalids in bed. The church is on rising ground at the edge of the chalk platform which lies below the Chilterns, some two miles away from them. I was on the scaffolding erected for repairs to the church. At a little past nine-it could hardly have been later, I think, than 9. I5, if so late-I felt the church give what seemed like a fierce shudder. This seemed to begin on the east, rather to north, and travelled westwards nearly. By shudder I mean that a sort of vibration began, which almost instantly increased in intensity, reached a climax, and then rapidly decreased and died away. It seemed to me to begin slightly north of east, because I remember feeling (for what reason I can hardly say) that the cause was hidden from me behind the east end of the church. I was on the south side, some eighteen feet from the southeast corner. A moment after a whirlwind followed, which began, as I find, near the top of the slope north-east of the church, and followed the churchyard wall which bends round the churchyard to south-west. In a cottage on the junction of the Chalk and Gault (or very near the junction), according to the result of inquiries I have made of an invalid there, the pictures on a wall lying north-west and south-cast waved from and to the wall, but seemed also to move along it somewhat, i.e. north-west and south-east. Flower-pots on a table rocked in a direction almost east and west, and a window facing the south-east shook; her bed also, lying north-west and south-east, waved, and seemed as if giving way. This took place, she says, a little after nine. In a cottage on the Gault where another invalid was lying, a window facing south-west rattled, a picture shook on the wall on which it is fixed, and the bed, lying south-east and north-west, also waved. This was, she thought, at nine, but the time must have been later. She noticed that the wind was still. No noise was heard except the clatter caused by the rattling of the buildings; but at a mill on the Icknield Way, near 'Tring, lying at nearly lat. $5 \mathrm{I}^{\circ} 48^{\prime}$, and long. $0^{\circ} 40^{\prime}$, a rumbling was heard.

Masworth Vicarage, Tring, May 6

\section{Black Rain}

THE following paragraph from the Ficld of May 3 will probably interest those of your readers who have seen my note in the last number of NATURE (p. 6) :-

"Black Rain.-Yesterday afternoon (April 28) a violent thunderstorm raged over the district between Church Stretton and Much Wenlock. Torrents of rain fell, seemingly a mixture of ink and water in equal proportions. One old man here says he never saw anything like it but once. I certainly never saw such a coloured rain, and I intend to have a bottle of it analysed. Even this afternoon the little brooks are quite black, and the ruts in the roads look as if ink and water had been poured into them.-Rev. R. I. BuddicomBE, Ticklerton, Church Stretton."

An analysis of the rain which fell at Stonyhurst showed that the impurity was almost entirely carbon.

Stonyhurst Observatory, Whalley, May 4

\section{The Remarkable Sunsets}

BECAUSE of the volcanic hypothesis that has been proposed to account for the red sunsets of the past fall and winter, other instances where similar phenomena have been seen after like eruptions are of interest.

Graham's Island, which arose off Sicily in I831, attracted attention from July 19 to August $\mathbf{I} 6$, but was most active on August 7 , according to the account given by John Davy in the Philosophical Transactions for 1832 . The same writer says (p. 252) :- "In the month of August a singular appearance was witnessed in the heavens, many evenings successively, both here and in Sicily. Soon after sunset the western sky became of a dark, lurid red, which extended almost to the zenith, and continued gradually diminishing in extent and intensity even beyond the limit of twilight."

A few days after this eruption, August II and 12, on the clearing away of a hurricane, the sun appeared blue at the Bermuda Islands (Amer. Journ. Sci. xl. p. 323); on August 13, I4, 15, at Mobile, in the southern part of the United States, the rays of the sun were pale blue or violet, varying to sea green (Amer. Journ. Sci. xxi. p. 198).

In the month of October the sunsets were prominent enough in the vicinity of Washington to attract popular inquiry. At Alexandria, Virginia, October I2, the heavens continued to reflect a very red light for a long time after the sun had set. October 13, at midday, the sun had a silvery appearance, and its rays gave a ghastly appearance to the countenances of persons. Between 3 and 4 p.m. it appeared greenish blue (Niles' Register, October I83I) L. G. CARPENTER

State Agricultural College, Lansing, Michigan, U.S.A., April 17

Ir may interest readers of NATURE to learn that on the occa. sion of a rain-storm at $5 \mathrm{p} . \mathrm{m}$. on the $26 \mathrm{th}$ ult. at Crowle, an agricultural village a few miles eastward of this city, the rainwater was so greatly discoloured and loaded with an ash-like matter as to present, until after subsidence, a deep black hue, when caught in vessels placed for the purpose. Again, on Saturday last, the 3 rd inst., on the occurrence in this city of rain-storms during a half gale from the north-west, there remained after the storms, on the panes of windows exposed to the north west, a considerable film of dust which had fallen with the rain. While writing it may be mentioned that the phenomenon described as red sunrises and sunsets has prevailed here, before and after sunset, ever since November 9 last ; of late, in gradually decreasing tone and variety of colour, and extent of sky area. The coloration at this date is of a russet hue, and there is a steely glare.

Worcester, May 5

J. LL. BOZWARD

\section{Rotating Thermometers}

In reference to the Froude thermometer, to which attention is drawn in your last number (p. 6) by Mr. Hazen, I feel confident that if its merits were better known it would be universally employed, not only as insuring among all observers absolute uniformity in the record of the temperature of the air, but as affording the only satisfactory means of determining the degree of saturation by means of the wet and dry bulb. Nothing is more perplexing to the meteorologist than the selection of his screen and of an appropriate site. The system of whirling a thermometer rapidly through the air effectually dwarfs all external influences from the rapidity with which renewed particles constantly impinge on the bulb, and it is well known that in the case of the wet bulb the indication is greatly affected by the presence or absence of wind. I found this to be practically the only means of determining the temperature and humidity in a steamer at sea. The only objection was the in convenience and risk of whirling small thermometers on a string, 